\title{
Knowledge, attitude and practice of prescribing antibiotics among dental practitioners in Chitwan
}

\author{
*Gita Paudel ${ }^{1}$, Arun Kumar Shah ${ }^{2}$, Anjan Palikhey ${ }^{3}$, Nikita Khanal ${ }^{4}$, Sirisa Karki ${ }^{1}$, Lokeshwar \\ Chaurasia $^{5}$, Rajib Chaulagain ${ }^{6}$
}

\section{Author Info:}

${ }^{1}$ Department of Pharmacology, Chitwan Medical College, Chitwan, Nepal

${ }^{2}$ Department of Oral and Maxillofacial Surgery, Chitwan Medical College, Chitwan, Nepal

${ }^{3}$ Department of Pharmacology, Universal College of Medical Sciences, Bhairahawa, Nepal

${ }^{4}$ Department of Dental and Oral Health, Bharatpur Samudayik Hospital, Chitwan, Nepal

${ }^{5}$ Department of Pharmacology, Janaki Medical College, Janakpur, Nepal

${ }^{6}$ Department of Oral Pathology, Chitwan Medical College, Chitwan, Nepal

\section{*Corresponding Author:}

Gita Paudel, Email/Contact: medrgita@gmail.com 9841415144

\section{ABSTRACT}

Background: Antibiotic resistance in recent years has become a major threat to public health globally. In dental practice, antibiotics and analgesics are commonly used for infection control and management of pain. The knowledge, attitude and practice skills of antibiotic prescription by dental practitioners should be continuously evaluated. The aim of this study was to assess the knowledge, attitude and practice regarding antibiotic prescription among dental practitioners.

Methods: A descriptive cross-sectional study was carried out to determine the knowledge, attitude and practice regarding antibiotic prescription among dental practitioners. A self-administered questionnaire was used to collect information which was adopted from previous studies. A briefing was given to the participants about the nature of the study and the procedure of completing the questionnaire was explained. After completion of the questionnaire, data was collected, reviewed, organized and expressed as counts/percentages and statically analyzed using SPSS version 16.

Result: The current study showed that majority of the participants had average knowledge $(52.7 \%)$ regarding antibiotic resistance but despite of that they have been prescribing antibiotic without proper guidelines. In this study, Amoxicillin (69.1\%) followed by amoxicillin-clavulanic acid $(25.5 \%)$ combination were the most commonly prescribed drugs used for the management of oral infections, but were prescribed based on symptoms without taking care of guidelines.

Conclusion: Dental practitioners had knowledge of antibiotic prescription and its resistance however they have been prescribing antibiotic without proper guidelines. It is deemed necessary to update the knowledge and enhance the careful use of antibiotics.

Keywords: Antibiotic, Attitude, Dentists, Knowledge, Practice, Resistance

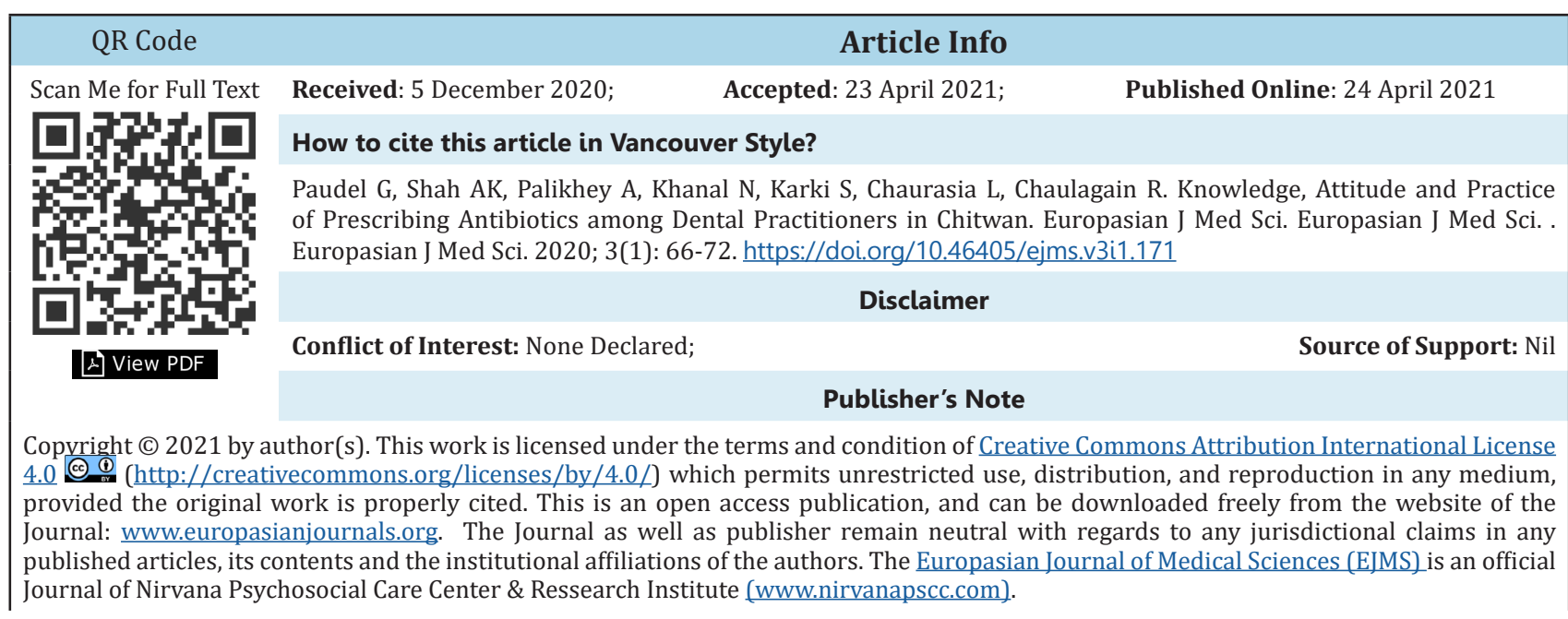




\section{INTRODUCTION}

The use of antibiotics in dentistry is getting usual and common and is mostly used for infection control. ${ }^{1}$ However, inappropriate prescriptions also don't provide benefits instead causes several adverse effects ranging from GI upsets to fatal anaphylactic shock and resistant bacterial emergence. ${ }^{2-4}$

Globally, in recent years antibiotic resistance has become a major threat to public health. ${ }^{5}$ The consequence of inappropriate use or overuse of antibiotics results in emergence of resistant bacterial strains and unfavorable side effects. This in turn leads to addition of budget loads on the national health system. ${ }^{6}$ A study conducted in UK has reported that $15 \%$ prescribe antibiotic on daily basis and 40\% prescribe antibiotics on at least three occasions. ${ }^{1,}$ ${ }^{7}$ Another study has shown that the most common prescribed antibiotic for treating endodontic infections was amoxicillin- clavulanate. ${ }^{8}$ An essential part of dentists is prescribing appropriate drug including antibiotics, thus proper knowledge about drugs safety, efficacy, convenience and cost is of significant value. Thus, dentists need to have absolute knowledge, information and recent advancement about drugs and be mindful of international rules of drug prescription. ${ }^{9}, 10$ Though there is evidential surge and expansion of antimicrobial resistance, but studies show dearth of appropriate knowledge in the dental community in this regard. ${ }^{11-14}$

Therefore, the aim of this study was to assess the knowledge, attitude and practice regarding antibiotic prescription among dental practitioners so that they can upgrade themselves and keep updated.

\section{MATERIALS AND METHODS}

A descriptive cross-sectional study was conducted among the dental practitioners at Chitwan, from $15^{\text {th }}$ June 2020 to $15^{\text {th }}$ July 2020. A convenience sampling method was utilized to collect the data from the dental practitioners in Chitwan. Due to the present pandemic of COVID-19, two methods were adopted to send the questionnaires to the participants: using google forms and few who were accessible were given printed questionnaires. All completely filled forms and only dental practitioners from Chitwan those who consented to participate, were included in the study. Anonymity and confidentiality of the data was assured among the participants.

In this study a self-administered questionnaire was used to collect information regarding the knowledge, attitude and practice of prescribing antibiotics among dental practitioners in Chitwan.
The questionnaire was adopted from previous studies $^{15-18}$ and modified after consultation with the experts related to the field. The questionnaire was pretested among 30 Dental surgeons outside Chitwan.

Based upon the response of pretesting, modifications were made and the final questionnaire was prepared which was used in the study. The self-administered questionnaire containing 26 questions was divided into five parts. The first part constituted of sociodemographic details of participants. The second part constituted of 5 questions related to knowledge regarding antibiotic, third part contained 9 questions related to attitude, fourth part contained 10 questions regarding practice and finally the last part was related to upgrading information with 2 questions.

Prior to data collection, the study was approved by Institutional Review Committee of Chitwan Medical College (Ref No. CMC-IRC/076/077-122). Data was collected, compiled and analyzed by using Statistical Package of Social Science (SPSS) version 16. The data was analyzed using descriptive statistics.

\section{RESULTS}

A total of 110 dental practitioners, 81 (73.6\%) females and 29 (26.4\%) males participated in the study and completed the questionnaire. Their mean age was $26.72 \pm 4.22$ years (Table 1 ).

More than half of the participants 57 (51.8\%) reported that antibiotics speed up the recovery of cold and cough. About 61 (55.5\%) of participants were in a view that the newer and higher price of antibiotics has no effect on efficacy. About 100 (90.9\%) knew about antibiotic resistance (Table 2).

About 79 (71.8\%) of participants disagreed on the fact that antibiotics was safe drug while 82 (74.5\%) disagreed on the fact that antibiotics are first drug of choice in cough, sore throat. Majority of the participants 94 (85.5\%) agreed that antibiotic resistance was a problem in Nepal. About 75 (68.2\%) were against keeping stocks of antibiotics at home (Table 3).

As shown in Table 4, out of 110 dentists surveyed, 61 (55.5\%) were prescribing antibiotics depending on symptoms. Most of the dental practitioners

Table 1: Sex wise presentation of dental practitioners $(\mathrm{n}=110)$

\begin{tabular}{|l|l|}
\hline Sex & Frequency (\%) \\
\hline Male & $29(26.4)$ \\
\hline Female & $81(73.6)$ \\
\hline
\end{tabular}


Table 2: Knowledge of antibiotics among the dental practitioners

\begin{tabular}{|c|c|c|c|}
\hline \multicolumn{3}{|c|}{ Variables } & \multirow{2}{*}{$\frac{N(\%)}{57(51.8)}$} \\
\hline \multirow{4}{*}{1} & \multirow{4}{*}{$\begin{array}{l}\text { The use of } \\
\text { antibiotics } \\
\text { on cold and } \\
\text { cough }\end{array}$} & Speed up the recovery & \\
\hline & & Prolongs the recovery & $1(0.9)$ \\
\hline & & Has no effect & $51(46.4)$ \\
\hline & & Don't know & $1(0.9)$ \\
\hline \multirow{4}{*}{2} & \multirow{4}{*}{$\begin{array}{l}\text { If the } \\
\text { antibiotics } \\
\text { are newer } \\
\text { and the } \\
\text { price is } \\
\text { higher }\end{array}$} & Efficacy is better & $25(22.7)$ \\
\hline & & Efficacy is worse & $1(0.9)$ \\
\hline & & Does not affect efficacy & $61(55.5)$ \\
\hline & & Don't know & 23 (20.9) \\
\hline \multirow{3}{*}{3} & \multirow{3}{*}{$\begin{array}{l}\text { Antibiotic } \\
\text { resistance }\end{array}$} & $\begin{array}{l}\text { Infection is not under } \\
\text { control even after } \\
\text { taking high doses of } \\
\text { antibiotics }\end{array}$ & $9(8.2)$ \\
\hline & & $\begin{array}{l}\text { Resistance acquired } \\
\text { by microorganism to } \\
\text { antibiotics }\end{array}$ & $\begin{array}{r}100 \\
(90.9)\end{array}$ \\
\hline & & Do not know & $1(0.9)$ \\
\hline \multirow{4}{*}{4} & \multirow{4}{*}{$\begin{array}{l}\text { Con- } \\
\text { sequences } \\
\text { of antibiotic } \\
\text { resistance }\end{array}$} & $\begin{array}{l}\text { May need more } \\
\text { expensive medicine }\end{array}$ & $30(27.3)$ \\
\hline & & May be sick for longer & $62(56.4)$ \\
\hline & & $\begin{array}{l}\text { May have to visit } \\
\text { doctor more }\end{array}$ & $14(12.7)$ \\
\hline & & Don't know & $4(3.6)$ \\
\hline
\end{tabular}

prescribed antibiotics in intra and extra oral draining sinus tract, acute facial swelling, dental trauma, pericoronitis, extraction by open method and periapical abscess. The top choice drug was Amoxicillin 76 (69.1\%) followed by Amoxicillinclavulanic acid 28 (25.5\%). Almost all dentists have undoubtedly responded positively regarding taking medical history. About 52 (47.3\%) of participants had excellent knowledge of prescribing antibiotics. While 16 (14.5\%) had positive attitude towards prescribing antibiotics, about 93 (84.5\%) had good practicing habit of prescribing antibiotics (Table 5).

\section{DISCUSSION}

The essential part of physicians and dentists is prescribing appropriate drugs, thus, proper knowledge about drugs safety, efficacy, convenience and cost is of significant value. Medically inappropriate, ineffective and economically inefficient use of the drugs occurs all over the world leading to antibiotic resistance and other serious consequences. Likewise, as per this study most of the dentists working in Chitwan had knowledge about antibiotic resistance and its consequences.

Antibiotics resistance in recent years has become a major threat worldwide. ${ }^{5}$ The present study exhibited that majority of the participants 100 (90.9\%) were acquainted with this. This was in line with the study conducted Gowri et al. ${ }^{19}$ and Konde et al. ${ }^{20}$

In the current study 61(55.5\%) prescribed antibiotics based on symptoms where they could have treated based on guidelines. In a similar study by Hammad et al. it was observed that majority of the dental practitioners did not follow the proper guidelines for antibiotic prophylaxis. ${ }^{21}$ This may be because the dental practioners are over burden with work and may find it difficult to keep themselves updated with

Table 3: Attitude of dental practitioners towards antibiotics

\begin{tabular}{|c|c|c|c|c|c|c|}
\hline & Variables & $\begin{array}{l}\text { Strongly } \\
\text { disagree }\end{array}$ & Disagree & Neutral & Agree & $\begin{array}{l}\text { Strongly } \\
\text { agree }\end{array}$ \\
\hline 1 & $\begin{array}{l}\text { Antibiotics are safe drugs, hence they can be } \\
\text { commonly used medication }\end{array}$ & $25(22.7)$ & $54(49.1)$ & $12(10.9)$ & $16(14.6)$ & $3(2.7)$ \\
\hline 2 & $\begin{array}{l}\text { Skipping one or two doses does not contribute } \\
\text { to the development of antibiotic resistance }\end{array}$ & $24(21.8)$ & $49(44.5)$ & $21(19.1)$ & $13(11.8)$ & $3(2.7)$ \\
\hline 3 & $\begin{array}{l}\text { Adverse effects of antibiotics are reduced by } \\
\text { using more than one antibiotics at a time }\end{array}$ & $13(11.8)$ & $48(43.6)$ & $21(19.1)$ & $21(19.1)$ & $7(6.4)$ \\
\hline 4 & $\begin{array}{l}\text { When you have a cough and sore throat, } \\
\text { antibiotics are the first drug of choice for } \\
\text { early treatment and to prevent emergence of } \\
\text { resistant strains }\end{array}$ & $26(23.6)$ & $56(50.9)$ & $9(8.2)$ & $19(17.3)$ & 0 \\
\hline 5 & Antibiotic resistance is a problem in Nepal & $1(0.9)$ & $5(4.5)$ & $10(9.1)$ & $63(57.3)$ & $31(28.2)$ \\
\hline 6 & It is good to keep antibiotic stocks at home & $23(20.9)$ & $52(47.3)$ & $17(15.5)$ & $18(16.4)$ & 0 \\
\hline
\end{tabular}


Table 4: Practice of dental practitioners towards the use of antibiotics

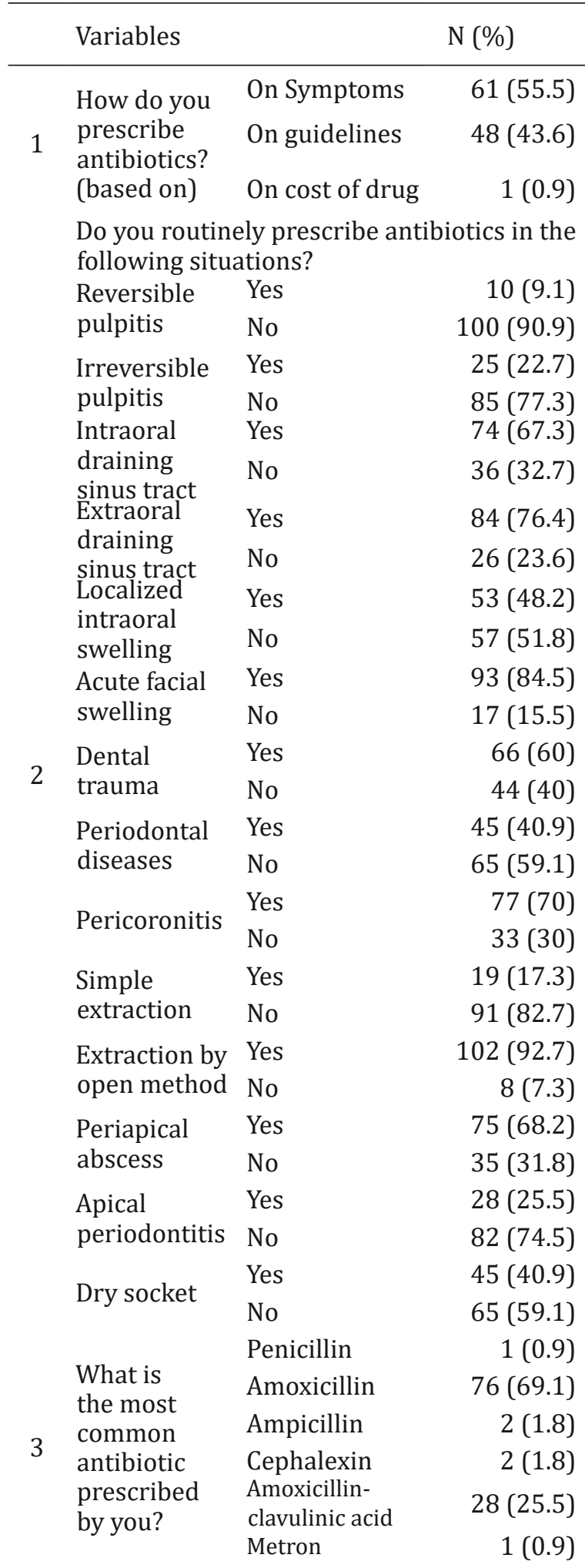

o you take medical history of the patient before prescribing antibiotics?

Yes

$110(100)$
Do you discuss the main side effects of antibiotic with your patients?

5 Yes

$88(80)$

Do you feel Always

pressure Often

6

from

Often

$29(26.4)$

patients to Sometimes

$66(60)$

prescribe Never

12 (10.9)

Table 5: Scoring of knowledge, attitude and practice

\begin{tabular}{lll}
\hline $\begin{array}{l}\text { Level of Knowledge, Attitude \& } \\
\text { Practice }\end{array}$ & $\begin{array}{l}\text { Frequency } \\
(\%)\end{array}$ \\
\hline Knowledge & Average knowledge & $58(52.7)$ \\
& Excellent knowledge & $52(47.3)$ \\
Attitude & Neutral Attitude & $94(85.5)$ \\
& Positive Attitude & $16(14.5)$ \\
Practice & Average Practice & $17(15.5)$ \\
& Good Practice & $93(84.5)$ \\
\hline
\end{tabular}

the current trends in prescription pattern.

In dental practice, antibiotics and analgesics are commonly used for infection controland management of pain. ${ }^{22,}{ }^{23}$ However, in dentistry conditions that need antibiotic therapy are mainly confined to oral infections aided by fever, lymphadenopathy and trismus. ${ }^{24}$ In certain situations such as acute periapical infection, dry socket, pulpitis and chronic inflammatory periodontal conditions antibiotics are not necessary whereas in acute periodontal conditions where drainage or debridement is not possible, antibiotics are prescribed. ${ }^{25}$ However, we observed that many dentists have consistently been prescribing antibiotics during infection, dry socket and pulpitis. Dry socket is one of the frequently faced state in dentistry and in most cases do not require antibiotics since it is not an infection, even so antibiotics are regularly recommended so far. ${ }^{26}$ Identical circumstances has been observed in our study where 45(40.9\%) participants would advocate antibiotics frequently for dry socket. Antibiotics are not indicated in periodontal conditions except for there is local spread of infection or where drainage or debridement is not feasible. ${ }^{27}$ In contrast to this participants in the current study asserted to advice antibiotics for periodontal conditions. The results perceived in this study where only $10(9.1 \%)$ and $25(22.7 \%)$ advised antibiotics for reversible and irreversible pulpitis respectively are sustained by a study done in Turkey in 2013 outlined a result of 
$6.1 \% .{ }^{28}$ One more study in United States also revealed lower results $16.8 \%{ }^{29}$ and a study conducted in Belgium reported $4.3 \%{ }^{30}$

Extraction of tooth is one of the most common procedure in dentistry where use of antibiotics has restricted advantage. ${ }^{31}$ Dentists around England and Scotland do not prescribe antibiotics during extraction unless necessary. ${ }^{32}$ Participants in this study indicated that only 19 (17.3\%) would recommend antibiotics for simple extraction and $109(92.7 \%)$ for extraction by open method.

About 75 (68.2\%) dental practitioners in our study has indicated antibiotics for periapical abscess which is in contrast to the study done in Turkey (41\%). ${ }^{28}$ This dissimilarity may be due to a number of factors ranging from inadequate knowledge to social factors, sample size, geographical differences.

The findings in this study clearly suggests that Amoxicillin $76(69.1 \%)$ followed by Amoxicillinclavulanic acid 28 (25.5\%) was the most routinely prescribed antibiotics and the similar result has been reported in a survey by Jayadev etal. ${ }^{33}$ In contradiction to this, a study done in United States claimed lower results $3.1 \%$ of participants prescribed Augmentin ${ }^{29}$ and one more study conducted in Belgium purported $22.1 \% .^{30}$

Self-medication is a common practice in Nepal and most people do not take full course of the drugs as advised by the consulting physician. When they think the symptoms have subsided they store those medication for future. Moreover, few studies have also documented the rise of antibiotic-resistant bacteria among farm animals and consumer meat and fish products. ${ }^{34-36}$

This study is, however, not devoid of limitation. First of all, the smallest sample size is the biggest limitation. Secondly this study focused on dentists of Chitwan so it cannot be generalized to all the dentists of Nepal. Thirdly, questionnaire-based study also has information bias.

\section{CONCLUSION}

The present study concluded that dental practitioners in Chitwan have knowledge regarding antibiotic prescription but there is an indisputable shortcoming in training and perception of dentists with regards to antibiotic guidelines. Therefore, with time the dental practitioners should update them for better practice of antibiotics

Acknowledgement: The authors would like to thank all the dental practitioners who have supported on being part of the study.

\section{REFERENCES}

1. Lewis MAO. Why we must reduce dental prescription of antibiotics: European Union Antibiotic Awareness Day. Br Dent J. 2008;205(10):537-8. https://doi.org/10.1038/sj.bdj.2008.984

2. Al-Haroni M. Bacterial resistance and the dental professionals' role to halt the problem. J Dent. 2008;36(2):95-103. https://doi.org/10.1016/j.jdent.2007.11.007

3. Lockhart PB, Blizzard J, Maslow AL, Brennan MT, Sasser H, Carew J. Drug cost implications for antibiotic prophylaxis for dental procedures. Oral Surg Oral Med Oral Patho Oral Radiol. 2013;115(3):345-53. https://doi.org/10.1016/j.0000.2012.10.008

4. Al-Johani K, Reddy SG, Al Mushayt AS, ElHousseiny A. Pattern of prescription of antibiotics among dental practitioners in Jeddah, KSA: A cross-sectional survey. Niger J Clin Pract. 2017;20(7):804-10.

5. Weber JT, Courvalin P. An emptying quiver: antimicrobial drugs and resistance. Emerg Infect Dis. 2005;11(6):791. https://doi.org/10.3201/eid1106.050471

6. Gyssens IC. Quality measures of antimicrobial drug use. Int J Antimicrob Agents. 2001;17(1):919. https://doi.org/10.1016/S09248579(00)00208-9

7. Segura-Egea J, Velasco-Ortega E, Torres-Lagares D, Velasco-Ponferrada M, Monsalve-Guil L, Llamas-Carreras J. Pattern of antibiotic prescription in the management of endodontic infections amongst Spanish oral surgeons. Int Endod J. 2010;43(4):342-50. https://doi.org/10.1111/j.13652591.2010.01691.x

8. Halboub E, Alzaili A, Quadri M, Al-Haroni M, Al-Obaida MI, Al-Hebshi NN. Antibiotic Prescription Knowledge of Dentists in Kingdom of Saudi Arabia: An Online, Country-wide Survey. J Contemp Dent Pract. 2016;17(3):198-204. https://doi.org/10.5005/ jp-journals-10024-1827

9. Asad S, Saba T, Hussain S, Ahmed M, Akram S, Khan A, et al. An ontology-based approach for detecting drug abuse epidemiology. Journal of Medical Imaging and Health Informatics. 2017;7(6):1324-37.

https://doi.org/10.1166/jmihi.2017.2253 
10. Mahmood A, Tahir MW, Abid A, Ullah MS, Sajjid M. Knowledge of Drug Prescription in Dental Students of Punjab Pakistan. PAKISTAN JOURNAL OF MEDICAL \& HEALTH SCIENCES. 2018;12(1):232-7. https:// pjmhsonline.com/2018/jan_march/ pdf/232\%20\%20\%20Knowledge\%20of\%20 Drug\%20Prescription\%20in\%20Dental\%20 Students\%20of\%20Punjab\%20Pakistan.pdf

11. Vessal G, Khabiri A, Mirkhani H, Cookson B, Askarian M. Study of antibiotic prescribing among dental practitioners in Shiraz, Islamic Republic of Iran. East Mediterr Health. 2011;17 (10), 763-9. https://doi. org/10.26719/2011.17.10.763

12. Zahabiyoun S, Sahabi M, Kharazi MJ. Improving knowledge of general dental practitioners on antibiotic prescribing by raising awareness of the Faculty of General Dental Practice (UK) Guidelines. J Dent (Tehran). 2015;12(3):171-6.

13. Laxminarayan R, Duse A, Wattal C, Zaidi AK, Wertheim HF, Sumpradit N, et al. Antibiotic resistance-the need for global solutions. Lancet Infect Dis. 2013;13(12):1057-98. https://doi.org/10.1016/S14733099(13)70318-9

14. Antibiotic resistance: long-term solutions require action now. Lancet Infect Dis. 2013;13(12):995. https://doi.org/10.1016/ s1473-3099(13)70290-1

15. Abu-Mostafa NA, Al-Mejlad NJ, Al-Yami AS, AlSakhin FZ, Al-Mudhi SA. A survey of awareness related to the use of antibiotics for dental issues among non-medical female university students in Riyadh, Saudi Arabia. J Infect Public Health. 2017;10(6):842-8.

https://doi.org/10.1016/j.jiph.2017.01.015

16. Chapagain S, Pokharel PK. Awareness among the Dental students and Dental Interns of Kantipur Dental College and Hospital regarding Antibiotics Prophylaxis for Infective Endocarditis. Journal of College of Medical Sciences-Nepal. 2019;15(2):112-8. https://doi.org/10.3126/jcmsn.v15i2.22162

17. Jairoun A, Hassan N, Ali A, Jairoun O, Shahwan $\mathrm{M}$. Knowledge, attitude and practice of antibiotic use among university students: a cross sectional study in UAE. BMC Public Health. 2019;19(1):518. https://doi.org/10.1186/s12889-019-6878-y

18. Jamshidi S, Shojaei S, Safari M. Evaluation of the Knowledge of General Dental Practitioners about Prophylactic Prescription of Antibiotics for Bacterial Endocarditis in Hamadan in 20112012. Avicenna Journal of Dental Research. 2018;4(2):100-13. http://ajdr.umsha.ac.ir/ Article/ajdr-56

19. Kannan S, Gowri S, Mehta D. Antibiotic use in dentistry: A cross-sectional survey from a developing country. Journal of Orofacial Sciences. 2015;7(2):90-4. https://doi. org/10.4103/0975-8844.164310

20. Konde S, Jairam LS, Peethambar P, Noojady SR, Kumar NC. Antibiotic overusage and resistance: A cross-sectional survey among pediatric dentists. J Indian Soc Pedod Prev Dent. 2016;34(2):145-51. https://doi. org/10.4103/0970-4388.180444

21. AL-Hammad N. Antibiotic prophylaxis for bacteria l endocarditis: A survey of current practices among dentists in Riyadh. Pakistan Oral and Dental Journal. 2006;26(1):79-92. http://podj.com.pk/archive/PODJ/Vol.\%20 26\%20(1)\%20(June\%202006)/26-01-79-92. pdf

22. Ramadan AM, Al Rikaby OA, Abu-Hammad OA, Dar-Odeh NS. Knowledge and Attitudes Towards Antibiotic Prescribing Among Dentists in Sudan. Pesquisa Brasileira em Odontopediatria e Clínica Integrada. 2019;19(1):1-10. https://doi.org/10.4034/PBOCI.2019.191.17

23. Zakri NI, Alshehri NM, Shebli AN. Antibiotic Practicing Habits, Knowledge and Attitude toward Education about Antibiotics among Dentists in Jazan City. Egyptian Journal of Hospital Medicine. 2018;72(3). https://doi.org/10.21608/ejhm.2018.9140

24. Swift JQ, Gulden WS. Antibiotic therapy-managing odontogenic infections. Dent Clin North Am. 2002;46(4):623-33. https://doi.org/10.1016/S00118532(02)00031-9

25. Salako N, Rotimi V, Adib S, Al-Mutawa S. Pattern of antibiotic prescription in the management of oral diseases among dentists in Kuwait. J Dent. 2004;32(7):503-9. https://doi.org/10.1016/j.jdent.2004.04.001

26. Chemaly D. How do I manage a patient with dry socket? Journal of Canadian Dental Association. 2013;79:d54. https://jcda.ca/article/d54

27. Addy M, Martin M. Systemic antimicrobials in the treatment of chronic periodontal diseases: a 
dilemma. Oral Dis. 2003;9:38-44. https://doi.org/10.1034/j.1601-0825.9.s1.7.x

28. Kaptan RF, Haznedaroglu F, Basturk FB, Kayahan MB. Treatment approaches and antibiotic use for emergency dental treatment in Turkey. Ther Clin Risk Manag. 2013;9:443-9. https://doi.org/10.2147/TCRM.S52009

29. Yingling NM, Byrne BE, Hartwell GR. Antibiotic use by members of the American Association of Endodontists in the year 2000: report of a national survey. J Endod. 2002;28(5):396-404. https://doi.org/10.1097/00004770200205000-00012

30. Mainjot A, D'Hoore W, Vanheusden A, Van Nieuwenhuysen JP. Antibiotic prescribing in dental practice in Belgium. Int Endod J. 2009;42(12):1112-7.

https://doi.org/10.1111/j.13652591.2009.01642.x

31. Barone A, Marchionni FS, Cinquini C, Toti P, Marconcini S, Covani U, et al. Antibiotic treatment to prevent postextraction complications: a monocentric, randomized clinical trial. Preliminary outcomes. Minerva Stomatologica. 2017;66(4):148-56. https://doi. org/10.23736/s0026-4970.17.04047-x
32. Palmer N, Martin M, Pealing R, Ireland $\mathrm{R}$, Roy K, Smith A, et al. Antibiotic prescribing knowledge of National Health Service general dental practitioners in England and Scotland. J Antimicrob Chemothe. 2001;47(2):233-7. https://doi.org/10.1093/jac/47.2.233

33. Jayadev M, Karunakar P, Vishwanath B, Chinmayi SS, Siddhartha P, Chaitanya B. Knowledge and pattern of antibiotic and non narcotic analgesic prescription for pulpal and periapical pathologies-a survey among dentists. J Clin Diagn Res. 2014;8(7):ZC10-4. https://doi.org/10.7860JCDR/2014/9645.4536

34. Cabello FC. Heavy use of prophylactic antibiotics in aquaculture: a growing problem for human and animal health and for the environment. Environ Microbiol. 2006;8(7):1137-44. https://doi.org/10.1111/j.14622920.2006.01054.x

35. Perreten V. Resistance in the food chain and in bacteria from animals: relevance to human infections. Frontiers in Antimicrobial Resistance: American Society of Microbiology; 2005. p. 446-64.

https://doi.org/10.1128/9781555817572.ch34

36. White DG, Alekshun MN, McDermott PF. Frontiers in antimicrobial resistance: a tribute to Stuart B. Levy: ASM Press; 2005. https://doi.org/10.1128/9781555817572 